\title{
Pelatihan Pengisian SPT Tahunan Orang Pribadi (OP) pada Mahasiswa Prodi Akuntansi Universitas Bumigora
}

\author{
R. Ayu Ida Aryani ${ }^{1}$, Ikang Murapi ${ }^{2}$, Dewa Ayu Oki Astarini ${ }^{3}$, Ni Ketut Sriwinarti ${ }^{4}$, \\ Khairan Marzuki ${ }^{5}$ \\ ayu.aryani@universitasbumigora.ac.id ${ }^{1}$, ikangmurapi11@universitasbumigora.ac.id², \\ Oki.astarini22@gmail.com ${ }^{3}$, sriwinarti@universitasbumigora.ac.id ${ }^{4}$, \\ khairan.marzuki@universitasbumigora.ac.id ${ }^{5}$
}

1,2,3,4,5 Universitas Bumigora

Article History:

Received: 07-12-2022

Revised: 11-01-2022

Accepted: 28-01-2022

\begin{abstract}
The community service program implemented at Bumigora University aims to carry out training activities with all students of the Accounting study program, in training on procedures for filling an Annual Personal Income Tax Return. The service material presented was training on reporting and filling out the Annual Personal Income Tax Return in hall 3 of the Bumigora University building. The method used in this activity namely by giving lectures / giving material followed by discussion and question and answer responsibility between presenters and participants in filling out the Annual Personal Income Tax Return. Training results The completion of the Annual Personal Income Tax Return is expected to make a significant contribution in the form of knowledge and skills that can be used as provisions in readiness to become a skilled workforce in the field of Accounting and Taxation to be able to compete in the world of work.
\end{abstract}

Keyword: Bumigora university, Students, Annual personal income tax return

\section{Pendahuluan}

Menurut Djadjadiningrat yang dikutip dari (Resmi, 2019) "Pajak sebagai suatu kewajiban menyerahkan sebagian dari kekayaan ke kas negara yang disebabkan suatu keadaan, kejadian, dan perbuatan yang memberikan kedudukan tertentu, tetapi bukan sebagai hukuman, menurut peraturan yang ditetapkan pemerintah serta dapat dipaksakan, tetapi tidak ada timbal balik dari negara secara langsung untuk memelihara kesejahteraan secara umum". Sementara menurut Andiriani yang dikutip dari (Pohan, 2014) "Pajak adalah iuran masyarakat kepada negara (yang dipaksakan) yang terutang oleh yang wajib membayarnya menurut peraturan-peraturan umum (undang-undang) dengan tidak mendapat prestasi kembali yang langsung dapat ditunjuk dan yang gunanya adalah untuk membiayai pengeluaran-pengeluaran umum berhubungan tugas negara untuk menyelenggarakan pemerintahan". Dengan salah satu sifat pajak yang tidak https://journal.universitasbumigora.ac.id/index.php/ADMA

E-ISSN: $2723-7370$ 
memberikan kontraprestasi /imbalan secara langsung kepada pembayarnya, membuat masih rendahnya kesadaran masyarakat untuk taat pajak kerana masyarat masih belum merasakan dampak pembayaran pajak secara nyata (Pajak, 2021).

Memasuki bulan Maret, Wajib Pajak khususnya Orang Pribadi mulai disibukkan dengan adanya pengisian dan pelaporan SPT Tahunan mengingat batas akhir pelaporan SPT Tahunan PPh Orang Pribadi itu sendiri jatuh pada akhir bulan maret. Hal ini juga yang membuat Prodi Akuntansi Universitas Bumigora mengajukan diselenggarakannya pelatihan pengisian SPT tahunan yang bertujuan untuk memberikan pengetahuan mengenai pelaporan, pengisian, dan penyampaian SPT Tahunan Orang Pribadi. Mengingat acara tersebut merupakan salah satu upaya peningkatan kegiatan akademik serta dalam rangka ikut serta pada kegiatan pajak pegabdian kepada masyarakat yakni menyebarluaskan pengetahuan tentang perpajakan di dalam maupun di luar lingkungan kampus.

Undang - undang Perpajakan menganut sistim self assessment, dimana Wajib Pajak diberi kepercayaan untuk menghitung, memperhitungkan, dan menetapkan besarnya jumlah (Kreston, 2021) Pajak Penghasilan yang terutang dan melaporkannya ke Kantor Pelayanan Pajak setempat setelah berakhirnya tahun pajak. Penetapan bentuk dan isi SPT tahunan yang menggunakan mata uang rupiah dan mata uang dollar Amerika Serikat diatur dalam peraturan Direktur Jenderal Pajak No. 39 / PJ / 2009 tanggal 2 Juli 2009 (Training, 2021).

Sudah merupakan kegiatan rutin tahunan bagi setiap perusahaan dan wajib pajak pada akhir tahun pajak melakukan pengisian dan pelaporan SPT PPh PPh Wajib Pajak Badan dan SPT Tahunan PPh Wajib Pajak Orang Pribadi. Wajib Pajak wajib mengisi Surat Pemberitahuan dengan benar, lengkap, dan jelas, dalam bahasa Indonesia dengan menggunakan huruf Latin, angka Arab, satuan mata uang Rupiah, dan menandatangani serta menyampaikannya ke kantor Direktorat Jenderal Pajak tempat Wajib Pajak terdaftar atau dikukuhkan atau tempat lain yang ditetapkan oleh Direktur Jenderal Pajak (Selvi et al., 2020).

Dengan menggunakan formulir SPT Tahunan PPh Wajib Pajak Orang Pribadi 1770 SS yang dapat di download dari Internet, peserta pelatihan dapat mengisi SPT dan melaporkan serta mempertanggungjawabkan penghitungan dan/atau pembayaran pajaknya dengan mudah, cepat dan dan benar sebelum batas akhir waktu penyerahan laporan SPT (Farwitawati, 2020). Melalui https://journal.universitasbumigora.ac.id/index.php/ADMA 
pelatihan ini mahasiswa prodi Akuntansi akan mendapat panduan dalam mengisi SPT dengan mudah, cepat dan benar dengan menggunakan komputer / lap top dalam format Excel. Pendampingan pengisian dan pelaporan SPT Tahunan PPh Wajib Pajak Orang Pribadi 1770 SS akan berkontribusi bagi negara dan wajib pajak dalam menjaga kepatuhan sebagai wajib pajak, serta sebagai wadah bagi dosen dan universitas dalam melakukan tridharma perguruan tinggi yaitu pengabdian kepada masyarakat (Henny \& Kurniawati, 2020).

Sementara itu, pelatihan diadakan di aula 3 gedung Universitas Bumigora yang di ikuti oleh seluruh Mahasiswa Program Studi Akuntansi yang ada di Universitas Bumigora. Rangkaian acara dimulai selama 3 hari, dari hari senin 22 Maret 24 Maret 2021. Para Dosen sebaagai narasumber dan peserta sangat antusias mengikuti kegiatan pelatihan pengisian dan pelaporan SPT Tahunan OP. Mereka aktif bertanya dan diskusi seputar masalah perpajakan yang mereka alami dan meminta solusi dalam permasalahan tersebut dan juga masih ada sebagian dosen yang belum memiliki NPWP. Sehingga melalui pelatihan ini diharapkan dapat meningkatkan kompetensi SDM dibidang perpajakan khususnya dalam hal pelaporan SPT Tahunan OP.

\section{Metode}

Metode pendekatan yang ditawarkan untuk memberikan informasi adalah melakukan pengabdian dengan memberikan penyuluhan-penyuluhan (Harapan, 2018) :

1. Meningkatkan pemahaman mahasiswa tata cara pelaporan SPT Tahunan PPh Orang Pribadi.

2. Memberikan pemahaman proses dan mekanisme perhitungan SPT Tahunan PPh Orang Pribadi.

3. Memberikan pemahaman pentingnya pelaporan SPT Tahunan khususnya SPT Tahunan PPh Orang Pribadi.

4. Terakhir adalah melakukan evaluasi hasil dengan mengobservasi kembali pemahaman mahasiswa mengenai tata cara pelaporan SPT Tahunan Tahunan PPh Orang Pribadi. 
Adapun rangkaian metode pendekatan yang ditawarkan digambarkan sebagai berikut:

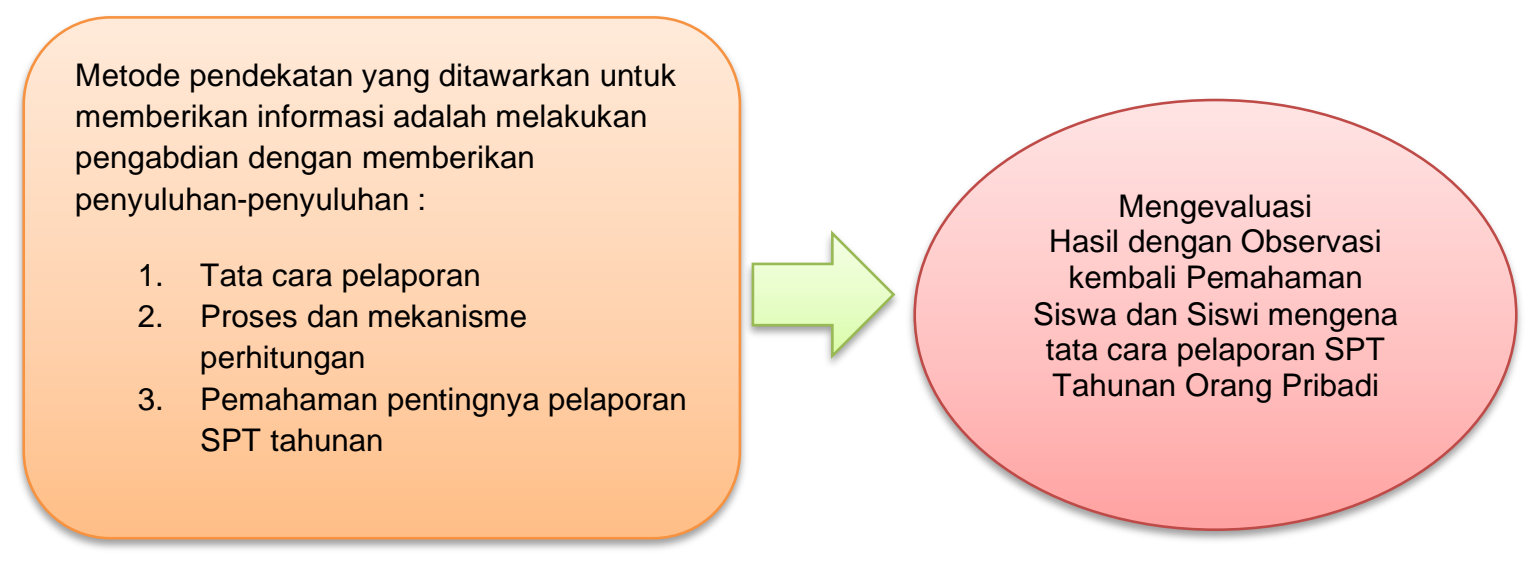

Gambar 1. Metode pendekatan

Prosedur kerja yang dilakukan untuk mendukung realisasi solusi yang ditawarkan, maka terlebih dahulu melakukan observasi awal di lapangan melakukan pendekatan melalui wawancara dan menemukan fenomena permasalahan (D. Training, 2021). Setelah observasi dan sosialisasi lalu dilakukan pengkajian permasalaan dan menemukan solusi yang hendak ditawarkan, selanjutnya menyusun prioritas tahap-tahap pelaksanaan dan selanjutnya barulah melakukan pengabdian dengan memberikan penyuluhan-penyuluan. Terahkir adalah melakukan evaluasi hasil dengan mengobserasi kembali pemahaman Mahasiswa Prodi Akuntansi mengenai pelaporan SPT Tahunan Orang Pribadi. Adapun seluruh rangkaian prosedur kerja dapat dilihat pada gambar dibawah ini (Harapan, 2018):

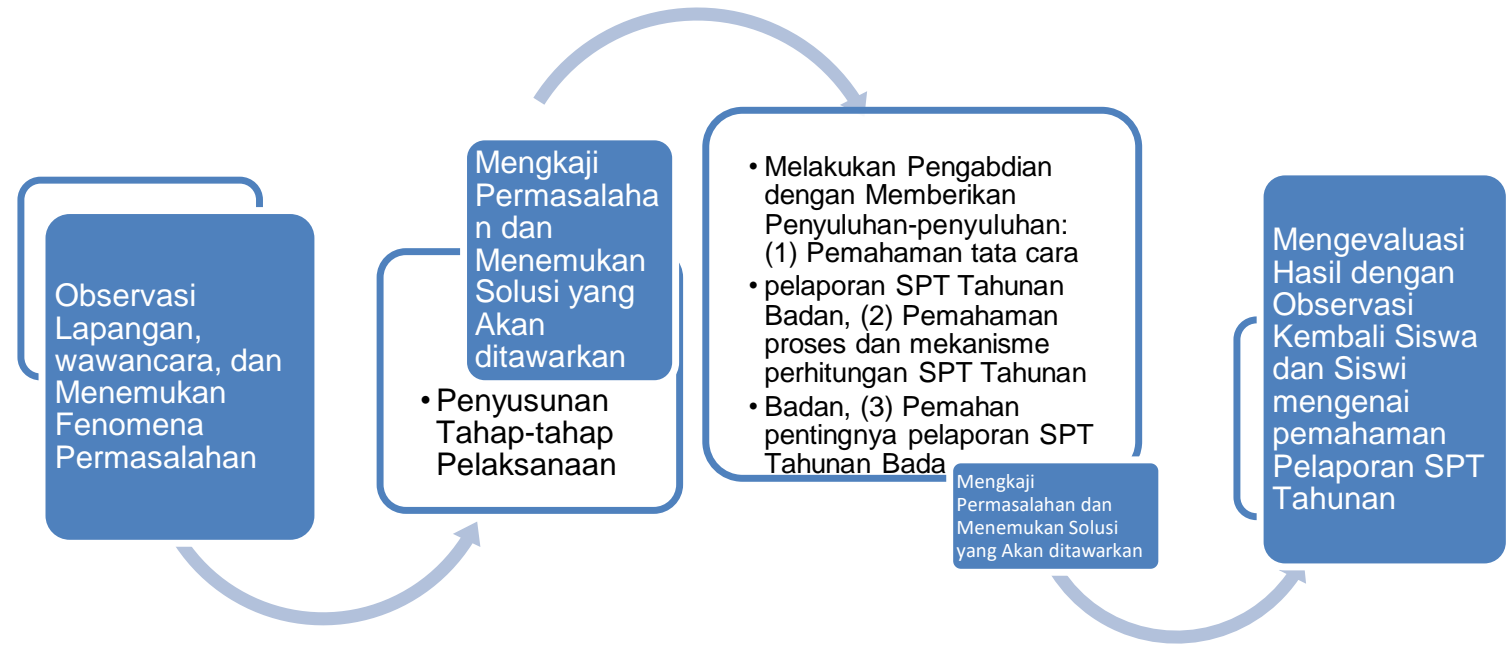

Gambar 2. Rangkaian prosedur kerja https://journal.universitasbumigora.ac.id/index.php/ADMA 


\section{Pembahasan}

Kegiatan pelatihan yang dilaksanakan dengan acara tatap muka dan praktek berjalan dengan baik dan lancar (C. Training, 2020). Pertemuan tatap muka dengan metode ceramah dan demonstrasi dilanjutkan dengan latihan untuk melakukan penghitungan dan pengisian SPT PPh Orang Pribadi. Kegiatan ini dilakukan pada 22-24 Maret 2021 mulai pukul 08.00-12.00 WIB. Peserta kegiatan adalah semua Mahasiswa prodi Akuntansi Universitas Bumigora. Dalam pelaksanaan pelatihan ini, materi yang disampaikan adalah sebagai berikut:

1. Dasar-dasar perpajakan

Narasumber memberikan informasi mengenai Pengertian Pajak, dimana pajak merupakan iuran wajib yang dibayarkan oleh rakyat kepada negara dengan tidak mendapat imbalan secara langsung berdasarkan Undang-undang dan dapat dipaksakan, yang digunakan untuk membiayai pengeluaran negara demi sebesar-besarnya kemakmuran rakyat. Narasumber juga memberikan informasi mengenai istilah-istilah yang sering digunakan dalam dunia perpajakan seperti, WP adalah Wajib pajak, SPT adalah Surat Pemberitahuan, KPP adalah Kantor Pelayanan Pajak, NPWP adalah Nomor Pokok Wajib Pajak, dan sebagainya. Peserta pelatihan juga diberikan informasi mengenai pentingnya membayar pajak dan uang yang telah dibayarkan wajib pajak kepada negara digunakan untuk berbagai hal seperti sektor pembangunan, kesehatan, pendidikan, kesejahteraan masyarakat dan masih banyak lagi.

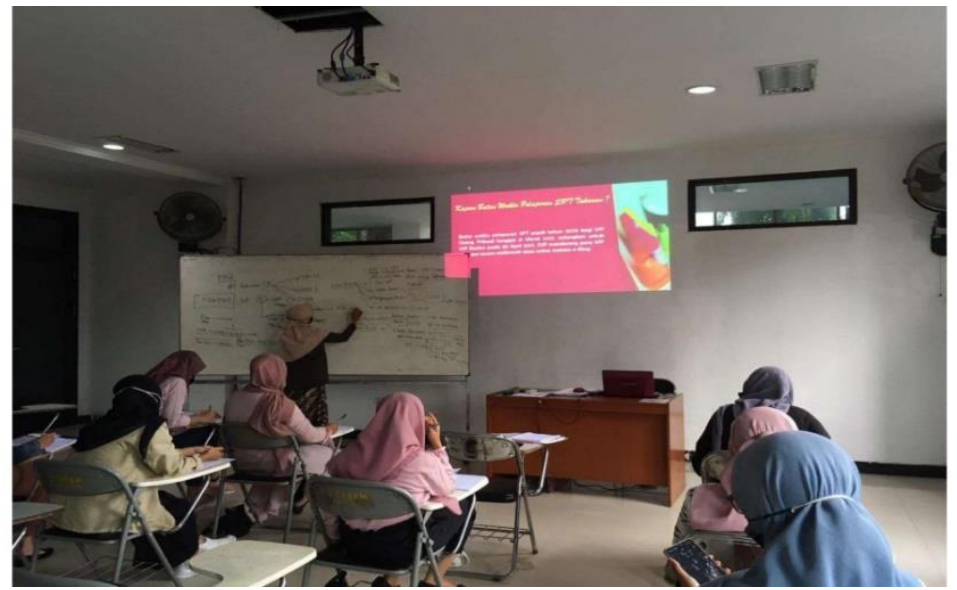

Gambar 3. Penyampaian materi pengantar perpajakan

https://journal.universitasbumigora.ac.id/index.php/ADMA

E-ISSN: 2723-7370 
2. Demonstrasi Penghitungan dan Pengisian SPT PPh Orang Pribadi

Narasumber memberikan contoh soal untuk dibahas bersama dalam mencari pajak terutang yang akan disetor dan dilaporkan oleh wajib pajak orang pribadi. Selanjutnya data yang telah dihitung di masukkan kedalam SPT Tahunan Orang Pribadi. SPT Tahunan Orang Pribadi terdiri dari 3 jenis, yaitu SPT 1770 SS yang diperuntukkan kepada kasryawan dari 1 pemberi kerja dan penghasilan brutonya dalam satu tahun pajak tidak lebih dari 60 juta rupiah, SPT 1770 S diperuntukkan bagi karyawan yang bekerja di satu atau lebih dari satu perusahaan dan memiliki penghasilan bruto dalam satu tahun pajak diatas 60 juta rupiah, dan yang terakhit SPT 1770 diperuntukkan bagi orang pribadi yang memiliki usaha atau menjalankan usaha bebas .

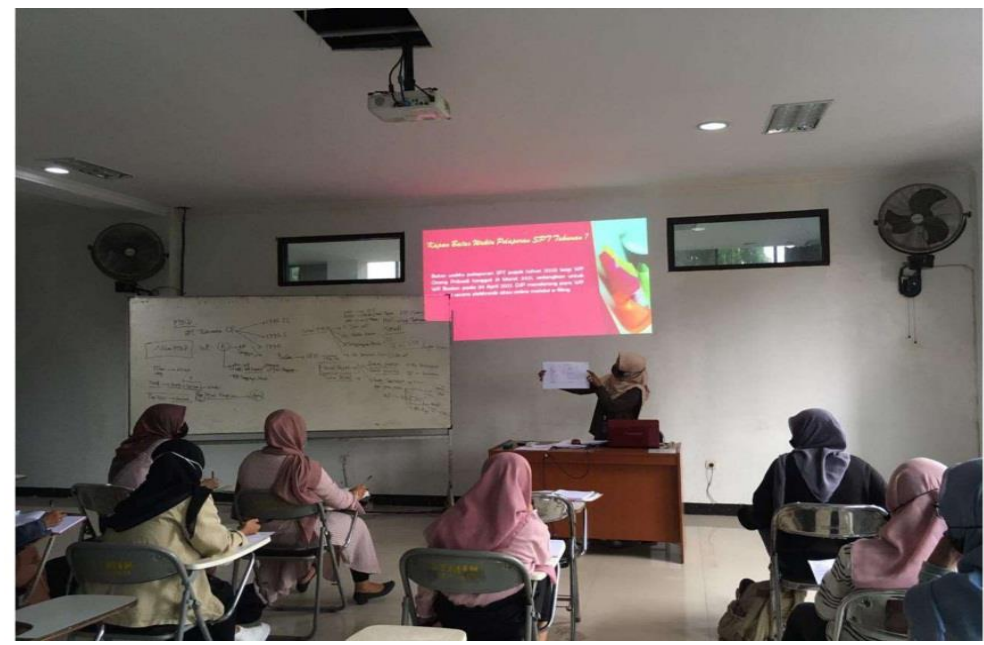

Gambar 4. Penyampaian simulasi pengisian SPT PPh orang pribadi

3. Latihan Penghitungan dan Pengisian SPT PPh Orang Pribadi

Peserta kegiatan workshop diberikan kesempatan untuk melakukan penghitungan dan pengsian SPT PPh Orang Pribadi seperti yang telah dicontohkan sebelumnya. Pertama yang dilakukan adalah melakukan penghitungan pajak terutang, kemudian dilanjutkan dengan menentukan jenis SPT yang akan digunakan dalam melaporkan pajak terutangnya. SPT diisi dimulai dari bagian lampiran paling terakhir dan dilanjutkan kebagian depannya dan seterusnya sampai ke bagian induk SPT.

https://journal.universitasbumigora.ac.id/index.php/ADMA 


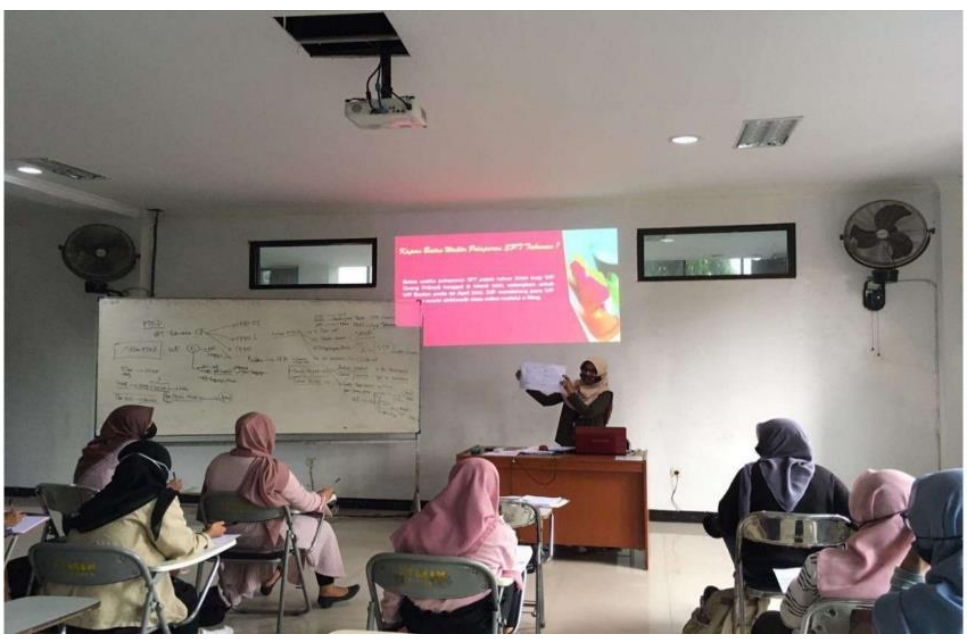

Gambar 5. Latihan penghitungan dan pengisian SPT PPh orang pribadi

Selanjutnya pelatihan Pengisian SPT PPh Orang Pribadi dilanjutkan dengan sesi tanya jawab. Adapun pertanyaan peserta berupa:

1. Penentuan besarnya Penghasilan Tidak Kena Pajak

2. Perbedaan masing-masing jenis SPT PPh

3. Dampak ketidakpatuhan di bidang perpajakan

4. Syarat seseorang harus memperoleh NPWP

Hasil kegiatan PKM secara garis besar mencakup beberapa komponen yakni:

1. Keberhasilan target jumlah peserta pelatihan

2. Ketercapaian tujuan pelatihan

3. Ketercapaian target materi yang telah dilaksanakan

4. Kemampuan peserta dalam penguasaan materi

Target peserta pelatihan ialah seluruh mahasiswa prodi Akuntansi Universitas Bumigora. Target peserta tercapai $100 \%$ yakni 72 orang mahasiswa hadir. Angka tersebut menunjukkan bahwa kegiatan PKM dilihat dari jumlah peserta yang mengikuti dapat dikatakan berhasil. Ketercapaian tujuan pelatihan secara umum sudah baik. Semua mahasiswa dapat melakukan pengisian SPT PPh secara manual. Namun, karena adanya keterbatasan media pembelajaran maka mahasiswa tidak dapat mempraktekkan e-filing. Ketercapaian target materi sudah cukup baik. Peserta mampu menjawab pertanyaan-pertanyaan yang diajukan narasumber seusai pemberian materi. Kemampuan peserta dapat dikatakan cukup baik dalam hal melakukan https://journal.universitasbumigora.ac.id/index.php/ADMA 
penghitungan dan pengisian SPT PPh Orang Pribadi. Namun demikian, pserta masih belum dapat mempraktekkan pengisian e-filing.

\section{Kesimpulan}

Kegiatan pengabdian kepada masyarakat yang telah dilakukan melalui pemberian video yang telah direkam sebelumnya mengenai pengisian dan pelaporan SPT Tahunan PPh Wajib Pajak Orang Pribadi 1770 SS secara manual mendapatkan respon yang baik dari peserta kegiatan, dimana peserta kegiatan mampu memahami materi kegiatan. Oleh karena itu, peserta kegiatan meminta kembali pembekalan topik selanjutnya yaitu pengisian dan pelaporan SPT Tahunan PPh Wajib Pajak Orang Pribadi 1770 SS menggunakan e filing di semester depan. Hambatan yang ditemui dalam pelaksanaan kegiatan ini adalah waktu yang singkat sehingga materi yang disampaikan harus dikelola menjadi lebih padat namun tetap dapat dimengerti dan poin yang hendak disampaikan dapat diterima dengan baik oleh peserta kegiatan.

\section{Ucapan Terimakasih}

Ucapan terimakasih ditujukan kepada semua dosen prodi Akuntansi yang telah membantu kelancaran kegiatan PKM, kepada semua Mahasiswa prodi Akuntansi yang mengikuti kegiatan pelatihan dengan semangat, dan pihak kampus yang membantu sarana dan prasarana sehingga kegiatan PKM bisa berjalan sesuai dengan yang diharapkan.

\section{Daftar Pustaka}

Farwitawati, R. (2020). Pelatihan Pajak Dan Pelaporan SPT Wajib Pajak Orang Pribadi Dengan E-Filing Bagi Guru Sekolah Menengah Kejuruan (SMK) Perpajakan Riau. Diklat Review, 4(3), 271-275. https://ejournal.kompetif.com/index.php/diklatreview/issue/view/37

Harapan, P. (2018). Pelatihan Pengisian SPT Tahunan WPOP Dan Pelaporannya Dengan E-Filling Bersama Seluruh Dosen Di Politeknik Harapan Bersama Tegal. https://poltektegal.ac.id/berita/pelatihan-pengisian-spt-tahunan-wpop-dan-pelaporannya-dengan-efilling-bersama-seluruh-dosen-di-politeknik-harapan-bersama

Henny, H., \& Kurniawati, H. (2020). Pendampingan Pengisian Dan Pelaporan Spt Tahunan Pph Wajib Pajak Orang Pribadi 1770 Ss Dengan Menggunakan E-Filing. http://repository.untar.ac.id/id/eprint/14304

Kreston, I. (2021). Praktik Pengisian dan Pelaporan SPT Tahunan PPh Badan (Taining Online). https://pratamaindomitra.co.id/event/praktik-pengisian-spt-tahunan-pph-badan-online

Pajak, D. (2021). Relawan Pajak Universitas Terbuka Ikut Pelatihan Pengisian SPT Tahunan. https://www.pajak.go.id/id/berita/relawan-pajak-universitas-terbuka-ikut-pelatihan-pengisian-spttahunan

https://journal.universitasbumigora.ac.id/index.php/ADMA

E-ISSN: $2723-7370$ 
Pohan, C. A. (2014). Pembahasan Komperhensif Perpajakan Indonesia Teori dan Kasus. In Mitra Wacana Media (1st ed.). Mitra Wacana Media.

Resmi, S. (2019). Perpajakan: Teori dan Kasus Edisi 10 (10th ed.). Salemba Empat.

Selvi, S., Notika, R., \& Arimbhi, P. (2020). Membangun Kepatuhan Perpajakan Sejak Dini Melalui Workshop Pengisian SPT PPh Orang Pribadi di SMKN 10 Jakarta. Jurnal Komunitas, 2(2), 133-139.

Training, C. (2020). TRAINING PENGISIAN SPT TAHUNAN PAJAK. Casa Training. https://casatraining.id/training-pengisian-spt-tahunan-pajak/

Training, D. (2021). Training Tata Cara Penghitungan dan Pengisian SPT Tahunan dan PPH Badan. http://direktoritraining.com/training-tata-cara-penghitungan-dan-pengisian-spt-tahunan-dan-pphbadan/ 
